\title{
ZAKAT PAYMENT RATE IN JABODETABEK (Jakarta, Bogor, Depok, Tangerang And Bekasi) Indonesia Zakat Payment Rate in JABODETABEK
}

\author{
Anton Hindardjo ${ }^{1}$, Juhary Ali ${ }^{2}$, Cicih Ratnasih ${ }^{3}$ \\ \{anton.hindardjo@sebi.ac.id ${ }^{1}$, juhary.ali@aeu.edu.my², cicihhilali@yahoo.com³ \\ ${ }^{1}$ Sekolah Tinggi Ekonomi Islam SEBI, Jl. Bojongsari, Pondok Rangga Bojongsari, Depok Jawa Barat \\ 16517, Indonesia \\ ${ }^{2}$ Asia e University, Wisma SUbang Jaya, No. 106, J1 SS15/4 Subang Jaya 47500, Selangor, Malaysia ${ }^{2}$ \\ ${ }^{3}$ Universitas Borobudur, Indonesia
}

\begin{abstract}
The intention to pay Zakat is strongly influenced by the willingness of each individual to tithe. This phenomena has strongly increased the Zakat payment in Jabodetabek. It is related to the theory of reasoned relationships and supported by Ajzen and using the name Behavior Theory of Behavior and Technology Planned by using the Unified Theory of Acceptance and Use of Technology, Integrated marketing communication and Regulation. 106 people in Jabodetabek have been taken as samples in this research using the technique of Krejcie-Morgan tables. The data is then analysed using Multiple Regression Analysis at a significance level of 0.07 . The results showed that the Individual Variable had an influence on the payment of zakat of $71.4 \%$ through zakat intention $78.6 \%$. While the variable of Technology, Integrated Marketing Communication and Regulations do not have a commitment to the intention of tithe and payment.
\end{abstract}

Keywords: Individuals, Technologies, Integrated Marketing Communications, Regulations, Intention to Pay Zakat, Paying Zakat.

\section{Introduction}

Based on the actual data of the charity, charity and charity donations in 2016 by the official charity collecting organization, the amount of the collection has only reached the target of 5 trillion rupees, which means that the achievement of the collection is far beyond the expected potential [1]. According to Uzaifah's research, one of the reasons for this was the failure of Muzakk1 to use the services of the Amil Zakat Agency as a body to fulfill its obligations as a Muslim in performing charity. $44 \%$ of Muslims choose to donate their charity privately. The results show that mutual good, alturism, community psychology and the hope for rewards have a significant influence on charitable motivation, while the desire to exercise social responsibility has little effect. Previous studies on donation intentions used non-uniform terms to describe donation behavior. Examples: charitable giving is used by Mayo and Tinsley (2009); Leslie, Snyder, Glomb (2012); Smith and Schwarz (2012); Hyung Hur (2006); Hou, Eason, Zhang, (2014). Next is the term charity or charity used by Kraut (1973); Moely, Furco, Reed (2008), and Boers (2012); Cloud and Hameed (2014); Knowles, Hyde, White (2012); Snip (2011); Mejova, Weber and Garimella, Dougal (2014) use the term donation behavior.

Human behavior is also determined by their desires [2]. Meanwhile, Planned Behavior 
Theory states that there are several determinants of desire, namely attitude, subjective norms and Perceived Behavioral Control [3]. In 2003, Venkatesh, Morris and several other researchers developed another method of consumer acceptance called Unified Theory of Acceptance and Use of Technology (UTAUT). According to [4], the concept of integrated marketing communication is to integrate and coordinate various corporate communication channels to deliver clear, consistent, and engaging messages about their organizations and products. The responsibility of a Muslim has an impact on the behavior of his followers, and cannot be separated from accountability based on Islamic law such as trust, benefits, justice, legal certainty, integrity, and responsibility. This also includes Muzakki's transparency in carrying out zakat responsibilities and information accessible to the public. However, there are still no models that incorporate the four indicators of variables, which influence Muzakkî's desire to fulfill zakat claims.

Low levels of awareness of compulsory charity, low trust in BAZ and LAZ, as well as donor actions that still have short-term, non-centralized and interpersonal characteristics. Low incentives for zakat payers, especially with regard to zakat as one tax deduction. This causes zakat to be considered a double burden [1]. Integrated marketing communications (advertising, public relations, direct marketing, and personal sales) simultaneously influence muzakki's desire. Meanwhile, only two variables, namely advertising and public relations, have an effect on muzakki's desire. [5]. Use of online zakat payment or e-zakat. In addition, this aspect will pay special attention to the need for increased awareness and use of the e-zakat system. In addition, this study will establish the application of Unified Theory of Acceptance and Use of Technology or UTAUT to predict the use of e-zakat online system, achieve awareness level and use of e-zakat online system zakat payers, and determine the variation in awareness and use of the e-zakat online system [6].

\section{Importance of the study}

The expected benefits of this study are:

1. It is hoped that this study will contribute to developing knowledge and development of discourse and research on individuals, and the desire to pay zakat (donation).

2. This study hopes to contribute to the impact of technology on paying zakat through the intention of paying zakat.

3. This study is expected to contribute to the impact of integrated marketing communications on paying zakat through the intention of paying zakat

4. It is hoped that this study will contribute to the impact of regulations on paying zakat through the intention of paying zakat.

Based on the background of the study, problem statement, purpose of the study, literature review, conceptual framework, theory and empirical findings of previous research, the hypothesis of this study is as follows:

H1 : Individuals have a significant impact on paying zakat through the intention of paying zakat.

H2 : Technology has a significant impact on paying zakat through the intention of paying zakat.

H3 : Integrated marketing communications have a significant impact on paying zakat through the intention of paying zakat.

H4 : Regulation has a significant impact on paying zakat through the intention of paying zakat. 
H5 : Individuals, technologies, integrated communications and regulations have a significant impact on the intention of paying zakat and paying zakat.

\section{Concept Mapping}

\subsection{Theory of Reasoned Action}

The ability to understand an individual's behavior is a key topic in psychology. One of the most widely used theories is the Theory of Reasoned Action (TRA) or Fishbein and Ajzen (1975). This theory was further developed by Ajzen (1985) into the Theory of Planned Behavior (TPB) or Planned Behavior Theory used to predict individual behavior more specifically. This study has the basis of observations made in Indonesia on the relationship between attitudes and behavior. Studies that use Planned Behavior Theory as a basic conceptual framework do not yet have a measurement system that fits this theory.

The dimensions of attitude, subjective norms, and behavioral control developed from the interaction between the two psychological aspects that support these dimensions have not been widely considered in the design of survey variables. Nevertheless, TRACTED Theory of Descriptive Behavior was developed by Tzen's Ajzen to overcome measurement weaknesses that led to low correlations between attitudes and behaviors, as Seymour Epstein noted in his two articles that attracted psychologists in 1979 and 1980. Responding to this critique, Ajzen and Fishbein $(1972 ; 1973)$ proposed that the low degree of correlation between attitude and behavior is due to different levels of measurement. Attitude is measured at a very general level while behavior is measured at a specific level. For example, there have been studies on the impact of attitudes on family planning and the use of pregnancy prevention tools. In this study, attitudes were measured at a general level, namely attitudes toward family planning, while behavior was measured at a specific level, namely the use of pregnancy prevention tools. To improve the ability to predict attitudes toward behavior, the same level of measurement is required for both.

\subsection{Unified Theory of Acceptance and Use of Technology (UTAUT)}

UTAUT is one of the latest technology adoption models developed by Venkatesh, V, Morris, MG, Davis, G.B., Davis, F.D. [2]. UTAUT combines characteristics born of a combination of eight theories into one. The eight leading theories integrated into UTAUT are causal theory (TRA), technology acceptance model (TAM), motivation model (MM), planned behavior theory (TPB), TAM and TPB theory, PC usage model (MPCU), theory the dissemination of innovation (IDT) and social cognitive theory (SCT). UTAUT proved to be more effective than the eight stated theories that could explain 70 percent of the user variant. After evaluating the eight models, Venkatesh found seven constructs that were significant determinants of behavioral intention or behavioral use in each model. These constructs are performance expectations, business expectations, social influence, ease of use, attitude towards technology use, and self-efficacy. After the follow-up test, there are four main constructs that play an important role as direct determinants of behavioral intention and behavioral use, namely performance expectations, expectation of effort, social influence, and convenience. Other constructs were found to have little influence as a direct determinant of behavioral intention. In addition, there are four moderators namely gender, age, volunteerism, and experience used to moderate the effects of the four main constructs. 


\subsection{Integrated Marketing Communication}

Relationships with Donations Marketing or promotional communication is an activity to entice consumers to buy a product by spreading the benefits of the product. [7] highlights that marketing communications focus their efforts and efforts on influencing consumer beliefs, attitudes, reactions, and choices when choosing services or goods. There is a common concept commonly used in marketing communications called mixed promotion. The concepts of mixed promotion include advertising, sales promotion, public relations, individual sales, and direct marketing. With various channels of information delivery to potential customers and customers, it is increasingly important for companies to adopt the concept of integrated marketing communication [5]. According to [4], the concept of integrated marketing communication is to integrate and coordinate various business communication channels to deliver clear, consistent, and engaging messages about an organization and its products.

\subsection{Regulations that affect donation intentions}

In the Indonesian dictionary, the word 'rule' means a method designed to regulate and provide provisions that must be implemented and obeyed to ensure that things are done quickly and efficiently.

\subsection{Designing Early Structural Models}

In this structural model, we will examine the effect of each exogenous latent variable on the endogenous latent variable. The first structural model based on the framework of thought and previous research are as follows:

\subsection{Designing a Measurement Model}

The measurement model is a model that connects latent variables with manifest variables (variables that can be measured). In this study there were 4 latent variables with 30 manifest variables. The marketing mix latent variable consisting of:

1. Latent variables Individuals have 14 manifest variables

2. The latent variable Technology has 19 manifest variables

3. The latent variable Integrated Marketing Communication has 15 manifest variables

4. The latent variable Regulation has 8 manifest variables

5. The latent variable Intention has 4 manifest variables

6. The latent variable Paying Zakat has 5 manifest variables

\subsection{Testing of Structural Models (Inner Model)}

Testing the inner model or structural model is done to see the relationship between constructs, significance values and R-square of the research model. The structural model is evaluated using R-square for the dependent construct of the $t$ test and the significance of the structural path parameter coefficients. 




Figure 1. Structural Model

In assessing the model with PLS it starts by looking at R-Square for each dependent latent variable. The image is the estimation result of R-Square using SmartPLS. Then the following table 4.2 will show the estimated results from R-Square.

\begin{tabular}{|l|c|}
\hline Variabel & R-Square \\
\hline $\begin{array}{l}\text { Intention to Pay } \\
\text { Zakat }\end{array}$ & 0.694 \\
\hline Paying Zakat & 0.510 \\
\hline
\end{tabular}

Table 2. Value of R-Square

The table above shows the R-Square value for the variable Intentions to Pay Zakat is 0.694 and the variable Paying Zakat is 0.510 . The result of R-Square value of 0.694 shows the relationship between Individual Variables, Technology, Integrated marketing communication and Regulations seen by Talent Intention of $0.694 \% .0 .306 \%$ other variables that influence tithing intentions.

And the R-Square value of 0.510 shows the relationship between Individual Variables, Technology Variable Technology, Marketing Communication and Integrated Regulations and the intention of Variable Mediation to pay zakat to zakat payment can be adjusted by paying zakat by $51 \% .49 \%$ of other variables that influence the behavior of paying Zakat.

\section{Conclusions}

1. Based on the result of the analysis, it can be concluded that of all variables only individual variable influenced the payment of Zakat through the intention to pay Zakat.

2. Technology variables, integrated marketing communications and regulations have no significant effect on the payment of zakat through zakat intentions 


\section{References}

[1] PUSKAS BAZNAS, Outlook Zakat Indonesia 2017. 2017.

[2] M. Khadafi, M. Heikal, and F. Falahuddin, "The Intention to Pay Zakat Commercial: An Application of Revised Theory of Planned Behavior," J. Econ. Behav. Stud., vol. 6, no. 9, pp. 727-734, 2014.

[3] I. Ajzen, "The theory of planned behavior," Organ. Behav. Hum. Decis. Process., 1991.

[4] K. O. Joseph, "Integrated marketing communication: A catalyst for the growth of Ebusiness management," Soc. Sci., vol. 6, no. 2, pp. 64-73, 2011.

[5] P. Komunikasi et al., "JESTT Vol. 1 No. 11 November 2014," vol. 1, no. 11, pp. 813831, 2014.

[6] N. N. Ahmad, M. Tarmidi, I. U. Ridzwan, M. A. Hamid, and R. A. Roni, "The Application of Unified Theory of Acceptance and Use of Technology ( UTAUT ) for Predicting the Usage of E-Zakat Online System," Int. J. Sci. Res., vol. 3, no. 4, pp. 6367, 2014

[7] C. D. Komunikasi, “464 Commonline Departemen Komunikasi| Vol. 3/ No. 3,” vol. 3, no. 3, pp. 464-473, 2012. 